\title{
Natural Zeolits and Its Modifications with Protons and Copper As the Catalyst for Esterification of Ethanol with Acetic Acid
}

\author{
Syukri ${ }^{1}$, Dini M. Islami ${ }^{1}$, Yoni Saputra ${ }^{1}$, Salmi Seprianti ${ }^{1}$, Sry Wahyuni ${ }^{1}$, \\ Fitria Ramadhani ${ }^{1}$, Syukri Arief ${ }^{1}$, Olly Norita Tetra ${ }^{2}$, Yulia Eka Putri ${ }^{1}$, and \\ Yetria Rilda'
}

${ }^{1}$ Inorganic Chemistry Laboratory Chemistry Department, Faculty of Mathematic and Natural Science, Andalas University, Padang, Indonesia

${ }^{2}$ Physical Chemistry Laboratory Chemistry Department, Faculty of Mathematic and Natural Science, Andalas University, Padang, Indonesia

\section{Abstract}

Natural zeolite from Cikalong, West Java has been modified by attaching protons and copper (II) to the framework. These materials are characterized by X-Ray Fluourescence (XRF), X-Ray Diffraction (XRD) and Fourier Transform Infra Red (FTIR). The results of the analysis with these tools show that the framework of the natural zeolite sample did not

Corresponding Author:

Syukri

syukri.darajat@yahoo.com

Received: 19 February 2019

Accepted: 5 March 2019

Published: 16 April 2019

Publishing services provided by

Knowledge E

(c) Syukri et al. This article is

distributed under the terms of

the Creative Commons

Attribution License, which

permits unrestricted use and

redistribution provided that the

original author and source are credited.

Selection and Peer-review under the responsibility of the ICBSA Conference Committee.

\section{G OPEN ACCESS} change significantly after modification. The catalytic activity of natural zeolite samples and their modified forms were tested as heterogeneous catalysts in esterification of ethanol with acetic acid. The chemical process was carried out at $75{ }^{\circ} \mathrm{C}$ for 4 hours with the presence of $5 \%$ catalyst weight and with the mole ratio of ethanol and acetic acid at 2: 1. Ethyl acetate products formed were analyzed by Gas Chromatography $(\mathrm{GC})$. In the catalytic test it was found that natural zeolites were more active than those modified with acid and copper, although the latter were also slightly better at reuse.

Keywords: Natural Zeolite, Catalyst, Esterification, Modification, Reuse

\section{Introduction}

Indonesia is a country that is rich in natural minerals such as zeolite, clay, and bentonite which is one of the advantages of the area with volcanic soil [1]. For example zeolite, it has been stated by the Indonesian Ministry of Energy and Mineral Resources that this country has no less than 400 million tons of zeolite deposits [2]. Naturally, zeolite occurs through a process of change on earth $[3,4]$. Most mordenite and clinoptilolite are natural zeolite types that are present in various content $[5,6]$.

It is well known that natural zeolite is commonly used as an adsorbent and catalyst. Many important organic reactions such as fat transesterification [7], bioethanol dehydration [8], and hydrocarbon cracking are processes that use zeolite as a catalyst [9]. Natural zeolite is generally used as a catalyst because of its good thermal, mechanical 
and chemical stability [10]. Then when compared with metal oxide catalysts, zeolite is more beneficial because of its abundance and requires low cost to use [11].

In recent years, many scientists have been interested in modifying natural zeolites to improve their performance as catalysts in organic reactions by treating zeolites with acids (mostly $\mathrm{H}_{2} \mathrm{SO}_{4}$ and $\mathrm{HCl}$ ) and transition metals such as $\mathrm{Fe}$ and $\mathrm{Cu}$ [12-15]. In the case of Cu-modified zeolites, it has been reported that copper-containing zeolites show better results compared to other zeolites with different metal transitions in oxidative dehydrogenation of methanol [16].

Ethyl acetate is one of the important chemical compounds used in many applications such as chemical reagents, coating agents, adhesives, perfumes and the pharmaceutical industry, solvents and plasticizers [17, 18]. Usually formed by esterification between ethanol and acetic acid with the help of a homogeneous catalyst. Sulfuric acid is the best homogeneous catalyst for the esterification process, because of its selectivity. However homogeneous catalysts have many disadvantages such as corrosive, environmental problems and difficult to separate [17]. This factor also has implications for many researchers to pay more attention to the development of heterogeneous catalysts that are environmentally friendly [19].

The synthesis of ethyl acetate catalyzed by zeolite is good to be studied further, because ethyl acetate is important in various applications, especially for organic reactions [20]. The use of natural zeolite as a heterogeneous catalyst for the fabrication of ethyl acetate is rarely reported. In this study, natural zeolite was modified using sulfuric acid and copper sulfate. Therefore, in this article we present a comparison of the catalytic capabilities between the original form and the modified form of natural zeolite obtained from the Cikalong area, West Java province, Indonesia.

\section{Materials and Methods}

\subsection{Materials}

Natural zeolite obtained from Cikalong West Java was purchased from Brataco co Itd while $97 \%$ sulfuric acid, $96 \%$ ethanol, and glacial acetic acid were purchased from Merck.

\subsection{Instruments}

The chemical composition was measured by PAN analytical Epsilon 3n X-Ray Fluorescence (XRF). X-Ray Diffraction Data (XRD) of zeolite powder was collected with Philip 
X'pert Powder Type PW4030/60). The IR spectra were measured by a Thermo Scientific Fourier Transform Infra Red (FTIR) spectrometer. Esters products are measured with Gas Chromatography - Mass Spectrometry (GC-MS) of Chromeleon 7 Thermo Fischer Scientific 7.2.4.8179.

\subsection{Catalyst preparation}

A certaint amount of zeolites are grounded using a mortar to increase the surface area, then suspended into distilled water for 24 hours. Zeolite suspension is filtered and dried using an oven below $150^{\circ} \mathrm{C}$ for 3 hours. Dry zeolite (labeled NZC) was further analyzed using XRF, XRD and FTIR.

\subsection{Acid treatment}

$0.5 \mathrm{M}$ sulfuric acid was prepared by diluting $6.94 \mathrm{~mL}$ of $97 \%$ sulfuric acid to $250 \mathrm{~mL}$ with distilled water. Zeolite is stirred together with $0.5 \mathrm{M}$ sulfuric acid for 24 hours with a ratio of zeolite to sulfuric acid is $1: 10$. The suspension is then filtered and the catalyst solids obtained are washed with distilled water. Then the catalyst was dried in an oven at $100{ }^{\circ} \mathrm{C}$ for 3 hours. The catalysts were labeled as $\mathrm{HZ}$ and characterized using XRF, XRD and FTIR.

\subsection{Copper treatment}

0.5 M Copper solution obtained from dilution of 31.2 grams of $\mathrm{CuSO}_{4} \cdot 6 \mathrm{H}_{2} \mathrm{O}$ into 250 $\mathrm{mL}$ of distilled water at a ratio of $1: 10$. Zeolite is stirred together with $0.5 \mathrm{M}$ copper solution for 24 hours with a ratio of 1: 10. Suspension filtered and solids washed with distilled water. Here the catalyst is dried in an oven at a temperature of $100{ }^{\circ} \mathrm{C}$ for 3 hours. Catalysts were named CuZ and characterized by XRF, XRD, and FTIR.

\subsection{Catalytic activity test}

All prepared catalysts (NZC, $\mathrm{HZ}$ and $\mathrm{CuZ}$ ) were tested on the synthesis of ethyl acetate. The ester derived from the esterification of ethanol by acetic acid with the molar ratio of alcohol to acid was 2:1 and 5\% by weight of the catalyst. The reaction is carried out in a simple reactor for 4 hours at $75^{\circ} \mathrm{C}$ where the reactor is equipped with a round bottom flask, condenser, and batch of water. The result is cooled at room temperature, and the 
solid catalyst is separated from the solution. The product predicted ester is distilled in a $250 \mathrm{~mL}$ round bottom flask and analyzed by gas chromatography. The catalyst was washed with distilled water and dried in an oven at $100{ }^{\circ} \mathrm{C}$ for 3 hours, so that it was weighed and reused for two more catalytic activities.

\section{Results}

\subsection{XRF analysis of the prepared catalysts}

Natural zeolite from Cikalong West Java (NZC) used in this study has a greenish color where silica and alumina are the main compounds (Table 1). Potassium is the most metal element found in zeolite samples followed by calcium, magnesium, iron and copper. Because natural zeolite has a high Si/Al mole ratio, zeolite structure cannot be solved with a low $\mathrm{pH}$ [21] and with high ion exchange capacity [22]. Theoretically, zeolites with a high Si/Al mole ratio can act as catalysts [23]. We can also state that NZC is a type of mineral with a hydrophobic surface because the mole ratio of $\mathrm{Si} / \mathrm{Al}$ is more than 4 which is good as a heterogeneous catalyst [21].

TABLE 1: XRF data of NZC, HZ and CuZ.

\begin{tabular}{l|c|c|c|c|c|c|c|c|} 
Catalysts & \multicolumn{7}{|c|}{ Metal oxide composition (\%) } \\
\hline $\mathrm{NZC}$ & $\mathrm{Al}_{2} \mathrm{O}_{3}$ & $\mathrm{SiO}_{2}$ & $\mathrm{~K}_{2} \mathrm{O}$ & $\mathrm{CaO}$ & $\mathrm{MgO}$ & $\mathrm{Fe}_{2} \mathrm{O}_{3}$ & $\mathrm{CuO}$ & $\mathrm{Si} / \mathrm{Al}$ \\
\hline $\mathrm{HZ}$ & 11.526 & 78.717 & 3.348 & 2.615 & 1.038 & 0.972 & - & 7.330 \\
$\mathrm{CuZ}$ & 9.671 & 82.806 & 2.795 & 1.499 & 1.422 & 0.791 & - & 9.390 \\
\hline
\end{tabular}

Increasing the mole ratio of Si/Al from the parent zeolite after being treated with acid $(\mathrm{HZ})$ as read in Table 1 can cause an increase in its absorption power [24]. This result is consistent with the theory that the reaction with acid can cause dealumination of zeolite [25] as depicted in Fig. 1. Meanwhile the treatment of NZC with copper (II) actually decreases the Si/Al ratio.<smiles>C[Si](C)(O)C[Si](C)(C)O[Si](C)(C)O[Si](C)(C)O[Si](C)(C)C</smiles>

Figure 1: Schematic illustration of the dealumination process [12]. 


\subsection{X-ray diffraction analysis of the prepared catalysts}

Fig. 2 shows the XRD pattern of natural zeolite before and after modification with acid and copper (II). The parent Zeolite, NZC, contains mordenite with orthorhombic crystal structures $\left(2 \theta 22.29^{\circ}, 13.4^{\circ}\right.$, and $\left.27.67^{\circ}\right)$ (ICDD 01-075-4223) as high minerals contained in natural zeolites. Other peaks at $2 \theta 25.64^{\circ}$ and $26.61^{\circ}$ are called heulandites with monoclinic crystal structures (ICDD 01-078-4509).

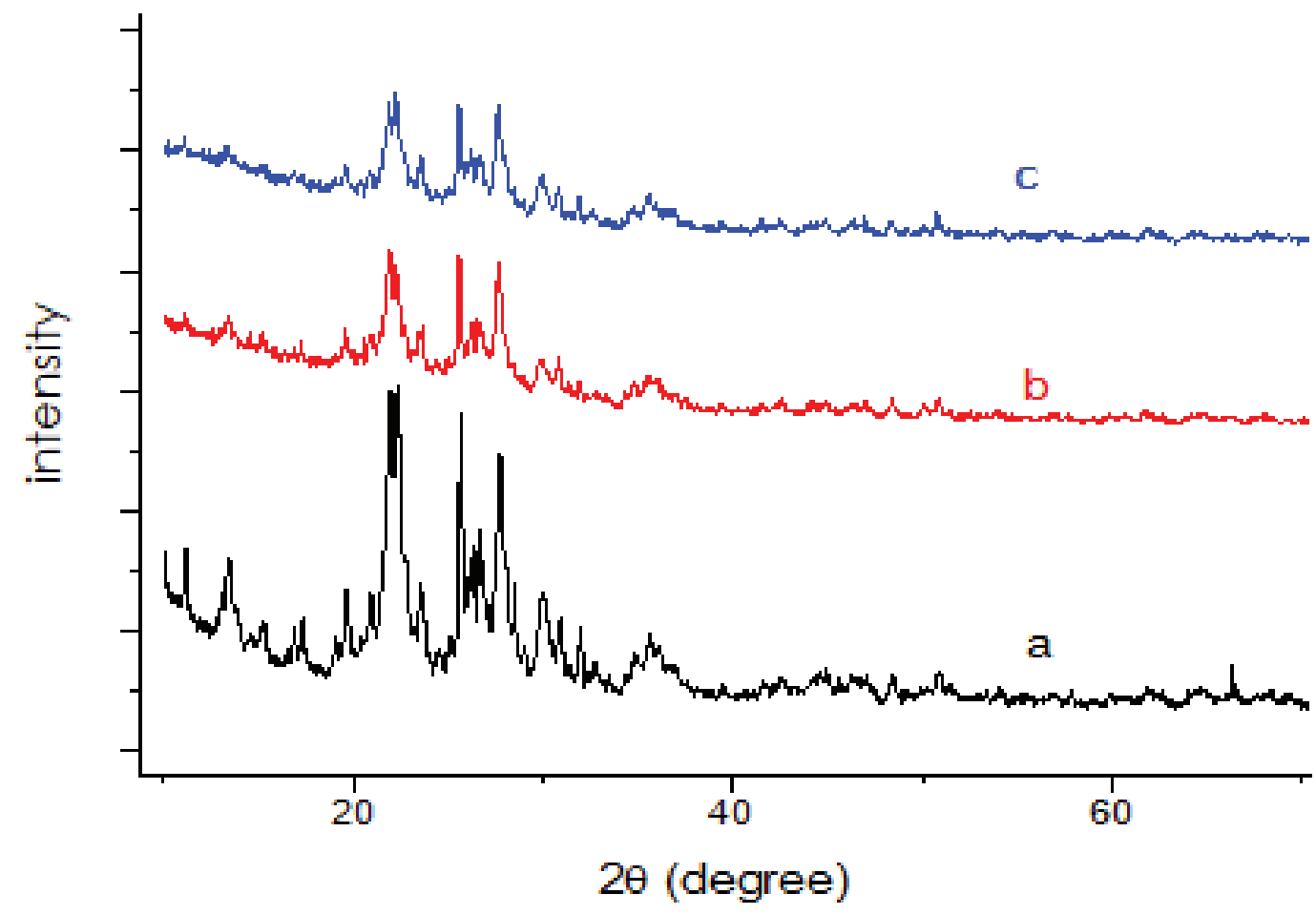

Figure 2: XRD pattern of NZC (a), $\mathrm{HZ}$ (b) and CuZ (c).

Furthermore, there are other minerals contained in the NZC sample, namely orthoclase and cristobalite. Orthoclase is indicated by $2 \theta 28.46^{\circ}$ and $29.84^{\circ}$. Both orthoclase and cristobalite are impurities in natural zeolites. Cristobalite is a polymorph of $\mathrm{SiO}_{2}$ which is included as quartz with different crystalline structures while orthoclase is a typical feldspar group. Natural zeolite from Cikalong contains mordenite as its main mineral with feldspar as an impurity [26]. Another report stated that natural zeolite from Bandung consisted of mordenite [27]. The XRD peak intensity of natural zeolite after being attached by acid and copper ions is only slightly shifted which shows that the structure of the parent zeolite has not changed much and once again shows the chemical stability of this natural mineral. 


\subsection{Fourier transform infrared analysis of the prepared catalysts}

Changes that might occur in zeolite structures were also analyzed using FTIR measurements. The main absorption peak can be observed at about $300-1300 \mathrm{~cm}^{-1}$ for $\mathrm{SiO}_{4}$ and $\mathrm{AlO}_{4}$ tetrahedral as the basic framework in the overall zeolite structure. Meanwhile the absorption peak in the $4000-1300 \mathrm{~cm}^{-1}$ region indicates a functional group consisting of zeolite. Fig. 3 shows the spectrum for each sample of NZC (a), HZ (b) and CuZ (c). We can see that absorption occurs at 575, 790, 1028, 2018, 2201; and $3624 \mathrm{~cm}^{-1}$.

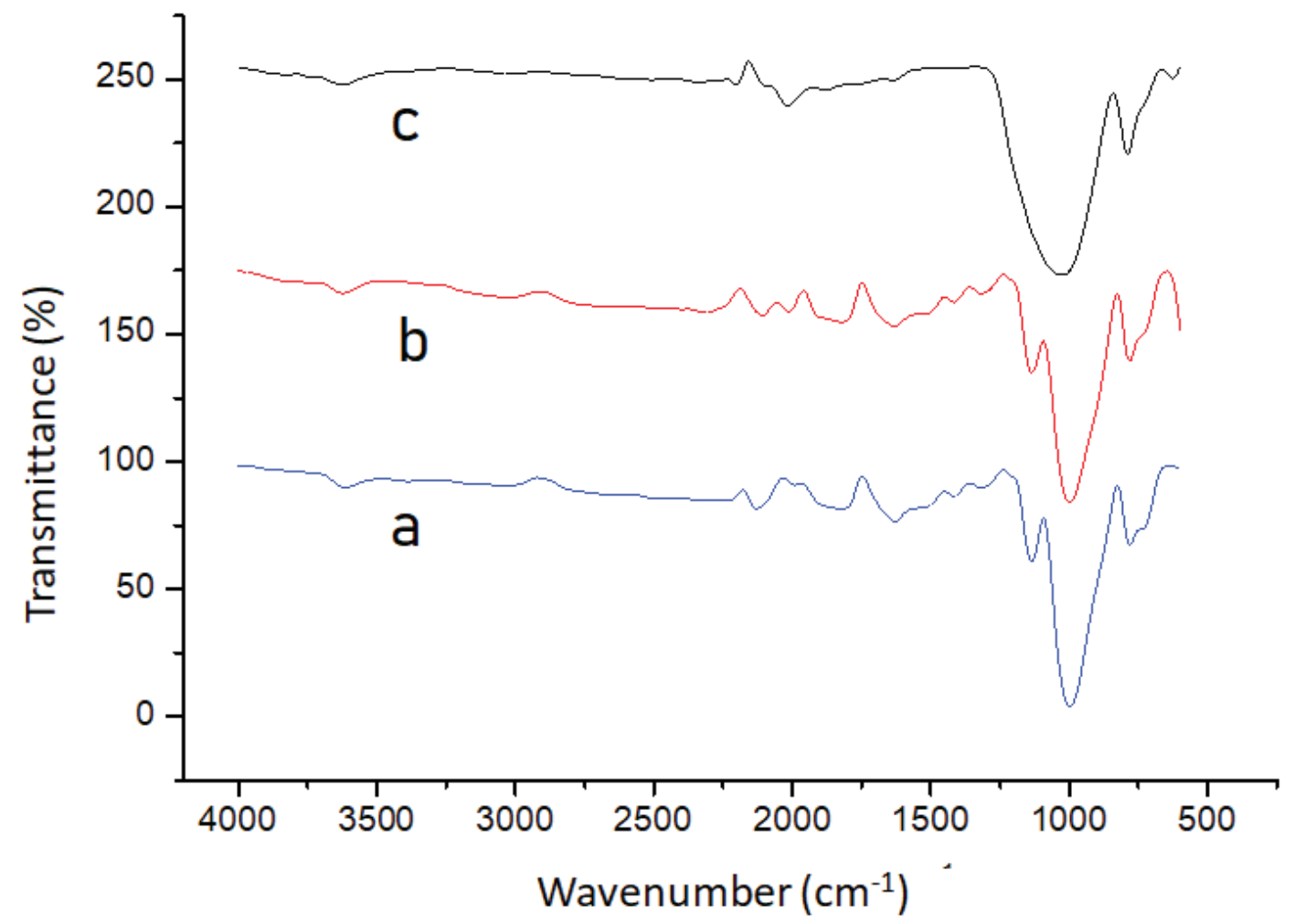

Figure 3: IR spectra of NZC (a) HZ (b) and CuZ (c).

The absorption peak at $575 \mathrm{~cm}^{-1}$ shows existing deformation and a mixture of aluminum and silicon vibrations [27]. The absorption peak at $790 \mathrm{~cm}^{-1}$, shows the existence of an O-T-O vibration in the external relationship of zeolite, where T may be Si or Al, while the absorption peak at $1028 \mathrm{~cm}^{-1}$ shows asymmetrical vibration stretching TOT (Si-O or Al-O) of the zeolite structure of TO4 [1, 37, 38 and 27]. Whereas the hydroxyl stretching vibration from the side of silanol can be observed in the absorption area of $3540-3650 \mathrm{~cm}^{-1}$. Table 2 shows the shift in peak of natural zeolite absorption. The shift shows the existence of zeolite external structural vibrations, which are caused by the loss of several Al atoms from the framework of zeolite structures after modification and possible changes in the bonding capacity and angle of Si-O-Si [1]. 
TABLE 2: The shifting of absorption peak of NZC, $\mathrm{HZ}$ and CuZ.

NZC

$790.21 \mathrm{~cm}^{-1}$

$1028.41 \mathrm{~cm}^{-1}$

$2201.32 \mathrm{~cm}^{-1}$

$3624.57 \mathrm{~cm}^{-1}$
$\mathrm{HZ}$

$782.22 \mathrm{~cm}^{-1}$

$1135.23 \mathrm{~cm}^{-1}$

$2010.64 \mathrm{~cm}^{-1}$

$3624.06 \mathrm{~cm}^{-1}$
CuZ

$780.63 \mathrm{~cm}^{-1}$

$1136.51 \mathrm{~cm}^{-1}$

$2131.20 \mathrm{~cm}^{-1}$

$3612.23 \mathrm{~cm}^{-1}$

Due to the interaction between $\mathrm{Cu}$ and $\mathrm{Al}$ with $\mathrm{OH}$ silanol of zeolite, the modification process using $\mathrm{CuSO}_{4}$ tends to shift the vibration absorption peak into a higher amount of absorption [16]. We can assume that the presence of bivalent cations such as $\mathrm{Cu}^{2+}$ causes the zeolite external structure to vibrate. New absorption peaks (Table 3) appear at 1136 and 1137 respectively in $\mathrm{HZ}$ and $\mathrm{CuZ}$ which show $\mathrm{TO}_{4}$ vibrations and also in the region of $1300-1650 \mathrm{~cm}^{-1}$ which shows the vibration of $\mathrm{H}-\mathrm{O}-\mathrm{H}$ from $\mathrm{H}_{2} \mathrm{O}$ absorbed.

TABLE 3: The absorption peak of $\mathrm{HZ}$ and CuZ.

\begin{tabular}{l|l|l|l|l|l|l|l|l|}
\hline $\begin{array}{l}\text { Modified } \\
\text { Zeolites }\end{array}$ & \multicolumn{7}{|c|}{ Absorption Peak $\left(\mathrm{cm}^{-1}\right)$} \\
\hline HZ & 782.22 & 999.14 & 1135.23 & 1318.23 & 1631.64 & 1819.86 & 2109.17 & 3624.06 \\
\hline CuZ & 780.63 & 997.96 & 1136.51 & 1319.25 & 1629.66 & 1821.98 & 2131.20 & 3612.23 \\
\hline
\end{tabular}

\subsection{Catalytic activity}

The catalytic activity of NZC, HZ and CuZ were tested on the esterification of ethanol with acetic acid (the molar ratio of ethanol to acetic acid was 2:1 and with the amount of catalyst $5 \%$ by weight of acetic acid). Ethyl acetate products are measured by GC-MS. The product shows a distinctive odor of ethyl acetate where the reaction equation is as follows:

As shown in Fig. 4, the first cycle clearly shows that NZC is better than $\mathrm{HZ}$ and Cuz. While for cycles two and three all catalysts show activities that are not too much different where the NZC remains slightly better. In the case of modification of zeolite with acid, as explained in the XRF characterization section, an increase in Si/Al ratio causes a decrease in its catalytic activity. When mixed with copper(II), the Si/AI ratio becomes lower which indicates that there are several silica frameworks that have been degraded, which also has an impact on the decrease in catalytic activity. Although not better than NZC, both $\mathrm{HZ}$ and $\mathrm{CuZ}$ showed catalytic activity that increased in the second cycle even though in the third one it returned which might be caused by the leaching of catalytic active centers to the solvent. 


$$
\mathrm{C}_{2} \mathrm{H}_{5} \mathrm{OH}+\mathrm{CH}_{3} \mathrm{COOH} \stackrel{\text { catalyst }}{\rightleftarrows} \mathrm{CH}_{3} \mathrm{COOC}_{2} \mathrm{H}_{5}+\mathrm{H}_{2} \mathrm{O}
$$

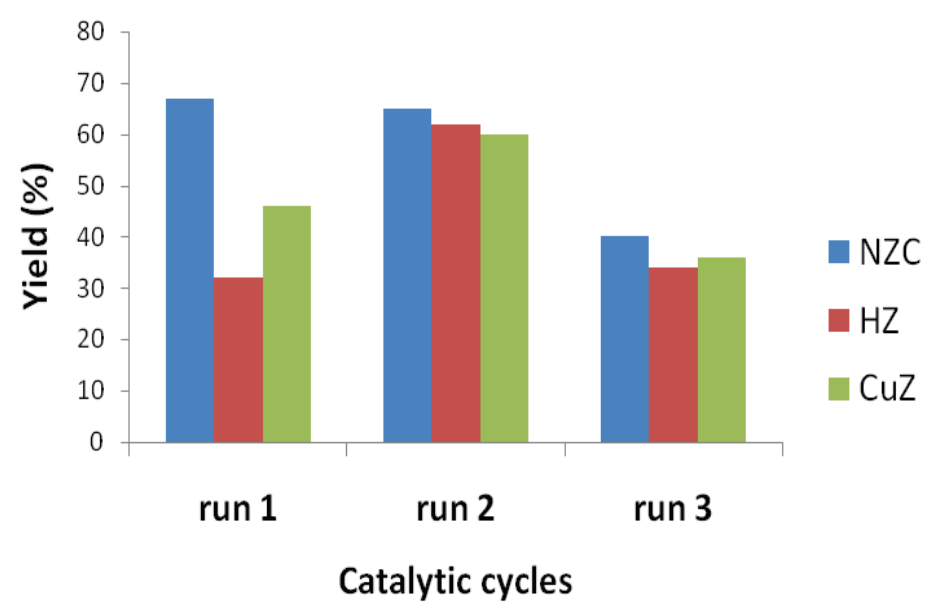

Figure 4: Catalytic test of NZC compared with both modification forms ( $\mathrm{HZ}$ and $\mathrm{CuZ}$ ) on esterification of ethanol with acetic acid for three reaction cycles.

\section{Conclusion}

From this work we can conclude that the Cikalong natural zeolite contains modernite and heulandite. Characterization with XRD shows that the structure of the natural zeolite crystal has not changed much after being modified with protons and copper(II). While measurements with XRF and FTIR indicated that there was a change in the Si/Al ratio which was opposite when natural zeolite was modified with acid compared with those modified with copper (II). The natural zeolite also shows catalytic activity which is generally better than the two modified forms of the mineral, but the latter is slightly better at reuse.

\section{Acknowledgment}

We the authors would like to express our deepest gratitude to FMIPA of Andalas University for funding this research with a Research Contract Number 15/UN.16.03.D/FMIPA/ 2018. We also expresses our gratitude to the Department of Chemistry of FMIPA of Andalas University for providing various laboratory facilities for the convenience of this research. Finally, we also thank you for the help of all parties involved in work. 


\section{References}

[1] Nurliati. G; Y.K Krisnandi; R. Sihombing; Z. Salimin; Studies of Modifiation of Zeolite by Tandem Acid-Base Treatments and its Adsorptions Performance Towards Thorium. Atom of Indonesia 2015. 41(2). 87 - 95.

[2] Kusdarto; Potensi Zeolit di Indonesia. Jurnal Zeolit Indonesia 2008. 7(2). 78 - 87.

[3] N. Wijayati; Utomo A. B.; Natural Zeolite Catalyst for Conversion of $\alpha$-Pinene. International Journal of Chemical Engineering and Application 2016. 7(2). 138 140.

[4] Majid. Arief Budiman; Wega Trisunaryanti; Yoga Priastomo; Erna Febriyanti; Syafitri Hasyyati; Again Nugroho; Karakterisasi dan Uji Aktivitas Katalitik Zeolit Alam Indonesia pada Hidrorengkah Ban Bekas dengan Preparasi Sederhana. Prosiding Seminar Nasional Kimia Unesa. Surabaya. 2012.

[5] Fatimah. Dewi; Modifikasi Zeolit Alam Melalui Penanaman Inhibitor Cu Dengan Metoda Batch Sebagai Bahan Baku Obat Anti-Septik. Jurnal Zeolit Indonesia 2009. 8(2). $66-75$.

[6] Mustain. Asalil; Gede Wibawa; Mukhammad Furoiddun Nais; Miftakhul Falah; Synthesis of Zeolite NaA From Low Grade (High Impurities) Indonesian Natural Zeolite. Indo. J. Chem 2014. 14 (2). 138 - 142.

[7] Kusuma. Ricky Indra; Johan Prabowo Hadinoto; Aning Ayucitra; Felycia Edi Soetaredjo; Suryadi Ismadji; Natural Zeolite from Pacitan Indonesia. As Catalyst Support for Transesterification of Palm Oil. Applied Clay Science 2013. 74. 121 126.

[8] Wahono. Satriyo Krido; Hernawan; Anis Kristiani; Silvester Tursiloadi; Haznan Abimayu; Characterization and Utilization of Gunungkidul Natural Zeolite for Bioethanol Dehydration. Conference and Exibition Indonesian Renewable Energy \& Energy Conservation: Energy Procedia 2014. 47. 263 - 267.

[9] Nurhadi. Mukhamad; Wega Trisunaryanti; M. Utoro Yahya; Bambang Setiaji; Characterization and Modification of Natural Zeolit And Its Cracking Properties on Petroleum Fraction. Indonesian Journal of Chemistry 2001. 1 (1). 7 - 10.

[10] Maisuradze. Giorgi; Shota Sidamonidze; Lali Akhal Bedashvili; Revaz Kvatasshidze; Modified Natural Zeolite as Catalyst for Catalytic Reduction of NO with CO-Main Components of Exhaust Gases. Journal of Environmental Science and Engineering 2015. 574-582.

[11] Gultom. Fransiskus; Pembuatan Nanozeolit Alam Sarulla Sebagai Pengisi Pada Polimer Foam Poliuretan. Agrium. 2015. 19 (3). 190 - 195. 
[12] Pawar. Ganesh T.; Sachin P. Gadekar; Balasaheb R. Arbad; Machhindra K. Lande; Modification. Characterization. and Catalytic Application of Mesolite for One Pot Synthesis of 3-Methyl-4-arylmethylene-isoxazol-5(4H)-ones. Bulletin of Chemical Reaction Engineering \& catalyst 2017. 12 (1). 32 - 40.

[13] Mohamed. Mohamed Mokhtar; Catalytic Properties of Fe lon-Exchanged Mordenit Toward The Ethanol Transformation: Influence of the Methods of Preparation. Journal of Molecular Catalysis A: Chemical 2003. 200. 301 - 313.

[14] Widiastuti. Endang; Kajian Awal Pembuatan Katalis Padat Berbahan Dasar Zeolit untuk Reaksi Esterifikasi. Race 2013. 7 (1).

[15] Kristiani. Anik; Sudiyarmanto Sudiyarmanto; Fauzan Aulia; Luthfiana Nurul Hidayati; Haznan Abimayu; Metal Suppoerted on Natural Zeolite as Catalysts for Conversion of Ethanol to Gasoline. MATEC Web of Conferences 2017. 101. 01001.

[16] Manafov. Manaf R.; Jeyran T. Rustamova; Goshgar S. Alifev; Irada G. Melikova; Adile M. Alijeva; Study of Modified Forms of Natural Zeolites as Catalysts for Methanol Oxidation. American Journal of Chemistry and Application 2015. 2 (6). 75 - 78.

[17] Hua. Yuan; Fan Xiaozhen; Zuo Shaoqing; Syhthesis of Ethyl Acetate Catalyzed by $\left(\mathrm{NH}_{4}\right)_{6}\left[\mathrm{MnMo}_{9} \mathrm{O}_{32}\right] .8 \mathrm{H}_{2} \mathrm{O}$ with Waugh Structure. Journal of hemical and Pharmaceutical Research 2015.7 (10). 445 - 448.

[18] Wu. Kuo-Ching; Yu-Wen Chen; An Efficient Two-phase Reaction of Ethyl Acetate Production in Modified ZSM-5 Zeolites. Applied Catalysts A: General. 2004. 257. 33 $-42$.

[19] Corma. Avelino; Hermenegildo Garcia; Sara Iborra; Jaime Primo; Modified Faujasite Zeolites as Catalysts in Organi Reactions: Esterification of Carboxylic Acids in the presence of HY Zeolites. Journal of Catalysis 1989. 120. 78 - 87.

[20] Inui. Kanichiro; Toru Kurabayashi; Satoshi Sato; Direct Synthesis of Ethyl Acetate from Ethanol Carried Out under Pressure. Journal of Catalysis 2002. 212. 207 215.

[21] Guerrero. Lailyn M.; Jenica F. Mendoza; Kim Thomas V. Ong II; Modification and Testing of Philippine Natural Zeolites as Potensial Alternative to Noble Metal Catalysts in Catalytic Converter. Thesis. Chemical Engineering. University of Santo Tomas. Philipine. 2016.

[22] Wahyuni. Santhy; Karakterisasi Zeolit Alam Asal Cikalong Tasikmalaya. Fakultas Matematika dan IImu Pengetahuan Alam. Universitas Padjajaran. Bandung. 2008.

[23] Nurhayati. Nanik Dwi; Modifikasi Zeolit Alam sebgai katalis melalui pengembanan logam tembaga. Seminar Nasional Kimia dan Pendidikan Kimia VIII. Surakarta. 2016. 
[24] Wibowo. E; M Rokhmat; Sutisna; R Murniati; Khairurrijal; M. Abdullah. Identification of Natural Zeolites from Sukabumi. West Java. Indonesia: Structure. Chemical Composition. Morphology and Molecular Vibration. Material Research Express. 2017. 4. 064002.

[25] Wirawan. S. K.; H. Sudibyo; Muhammad F. Setiaji; I. W. Warmada; Endang T. Wahyudi; Development of Natural Zeolite Adsorbent: Chemical Analysis And Preliminary TPD Adsorption Study. Journal of Engineering Science and Technology. 2015. 87 - 95.

[26] Wyantuti, S.; Karakterisasi Zeolit Alam Asal Cikalong Tasikmalaya. Bandung. Universitas Padjajaran. 2008.

[27] Srihapsari. Dwita.; Penggunaan Zeolit Alam Yang Diaktivasi Dengan Larutan $\mathrm{HCl}$ untuk Menjerap Logam-logam Penyebab Kesadahan Air. Skripsi. Fakultas Matematika dan Ilmu Pengetahuan Alam. Universitas Negeri Semarang. Semarang. 2006. 